\title{
LIST OF TABLES AND APPENDIXES
}

2.1

2.6

3.1

3.6

Appendix 3.1 Appendix 3.2 Appendix 3.3
Value-Added in Agriculture, Employment Levels, and Rural Population, Selected Southeast Asian States, 1960-2015

Per Capita Food Consumption (kg/year) and Self-sufficiency Level (SSL) (\%) in Main Food Types, 1975-2015

Value-Added per Month, per Worker in Agriculture by State, 2010 Prices (RM)

Share of Malaysia's Agricultural Gross Domestic Product, by State, 2005-16

Crop Area and Output, Johor, 2015 2015

Palm Fruit Mills in Johor, 1966-2017

Segments, Johor, 2017

Candidates, GE-13

Parliamentary Candidates, GE-14 vs. GE-13

92

Estimated Labour in Johor's Oil Palm Economy, 2010s

Built-up Areas in Johor, 1990-2014
Balm Oil Processing Equip

Existing Oil, Gas and Petrochemical (or Related) Activity in Malaysia 
Frequency and Spatial Distribution of Greenfield FDI in SIJORI by Oil and Gas Subsectors, Functions and World Region of Origin, 2003-16

5.1 Principal Statistics of Health Services by Selected States, 2010 and 2015

Principal Statistics of Hospital Services by Selected States, 2010 and 2015

$5.4 \quad$ List of Hospitals and Specialist Clinics in Johor According to MHTC and APHM Membership and Location

Appendix 7.1 Johor Tourism Development Clusters

Appendix 9.1 Parliamentary Seats Contested by MCA, MIC, and Gerakan, 2013

Appendix 9.2 State Constituencies Contested by MCA, MIC, and Gerakan, 2013 
Appendix 11.1 Slides Presented by Aminolhuda Hassan at the Meeting in

Bakri on 16 July 2015, Which Culminated with the Bakri

Declaration

Estimated Number of Undocumented Foreign Workers

Number of Foreign Workers by Sectors, Malaysia, 2018

Number of Foreign Workers by Source Country and Sector, Malaysia, 2018

Calculation on Percentage of Documented and

Undocumented Foreign Workers of Total Labour Force, Malaysia, 2018

Percentage Share of 338 Companies Surveyed, by Industrial Sector

List of Residences Developed by UEM Sunrise in Nusajaya, Flagship Zone B

Some Key Property Developments in Danga Bay and

Distribution of Newly Launched Houses in Johor Bahru, Affordable Housing Schemes Inside and Outside of Iskandar Malaysia

A Price Comparison between Key Residential Properties in Medini and Singapore

Comparison of Average Condominium Property Prices per square foot 
18.1 Items on the State List that may Affect Wholesale Implementation of Federally Constituted Environmental Laws 481

18.2 Comparison between Federal and State Entities that Govern or Manage the Environment

18.3 Selected Federal and State Laws and Regional Blueprints that Legislate and Guide Environmental Matters in Johor 484

18.4 Breakdown of Announced Components of 2019 Johor Budget 2019 492

Appendix 18.1 Selected Johor State or State-Linked Entities That May Influence Environmental Policy Environmental Policy 494 Appendix 18.2 Johor State Executive Committee Members and Their Relevant Environmental Domains, 2017 